\title{
Resurrecting Smelser: Collective Power, Generalized Belief, and Hegemonic Spaces
}

\author{
Mikaila Mariel Lemonik Arthur*
}

When people mobilize for collective action, it is because they want something. These wants are known as grievances, and in order for them to emerge, collectivities must break free of hegemonic power to see their true interests. This paper takes a new look at Smelser's The Logic of Collective Action and finds that by incorporating a robust understanding of power, Smelser's framework can provide an understanding of grievance emergence. [Article copies available for a fee from The Transformative Studies Institute. E-mail address: journal@transformativestudies.org Website: http://www.transformativestudies.org (C2009 by The Transformative Studies Institute. All rights reserved.]

KEYWORDS: Power, Repression, Consciousness, Grievances, Mobilization, Hegemony.

\section{INTRODUCTION}

When people organize collectively, it is because they want something. In other words, a group of people has somehow come to believe, as a group, that some aspect of their social life needs to be altered. Most inquiries into the worlds of social movements start after this belief has emerged.

\footnotetext{
* Mikaila Mariel Lemonik Arthur, Ph.D., is an Assistant Professor of Sociology at Rhode Island College; she teaches courses in research methods, the sociology of race, and law \& society to sociology and justice studies students. Her research is about social movements within organizations, with a particular focus on curricular change in higher education. Acknowledgements: I would like to thank Steven Lukes, Leslie-Ann Bolden, Cheryl Ann Holzmeyer, Benjamin Ledsham, and Dongtao Qi for their comments on earlier drafts, as well as the participants in Power, Domination, and Resistance, Spring 2004, for helping to clarify the ideas behind this paper. Earlier versions of this paper were presented at the 2005 American Sociological Association Annual Meetings in Philadelphia and at the New York University workshop on Power, Politics, and Protest. Address correspondence to: Dr. Mikaila Mariel Lemonik Arthur, Department of Sociology, Rhode Island College, 600 Mount Pleasant Avenue, Providence, RI 02906; tel: (401) 456-8681; e-mail: marthur@ric.edu.
} 